\title{
PENGARUH LINGKUNGAN KELUARGA BAGI ANAK TERHADAP PERKEMBANGAN ANAK
}

\author{
Haniefa Hebatullah \\ IIK Surya Mitra Husada Indonesia \\ haniefa.hebatullah@gmail.com
}

\begin{abstract}
Abstrak
Keluarga merupakan suatu lembaga pendidikan pertama dan utama, yang sangat menentukan masa depan suatu kehidupan keluarga. Keluarga juga merupakan suatu wadah dan tempat untuk tumbuh dan berkembangnya anak secara keseluruhan. Dengan demikian keluarga berarti mempunyai peranan yang sangat besar dalam membentuk jiwa dan kepribadian seorang anak, karena baik buruknya pribadi dan jiwa anak sangat tergantung dari keluarga atau kedua orang tuanya. Kepribadian merupakan suatu sifat yang menjadikannya sebagai ciri tersendiri dari orang lain yang tercerminkan dari tingkah laku, cara berbicara, dan cara berfikir. Seorang anak juga memiliki Hak dalam keluarga yang harus diberikan oleh keluarga, terutama kedua orang tua.
\end{abstract}

\section{Latar Belakang}

Anak adalah seorang lelaki atau perempuan yang belum dewasa atau belum mengalami masa pubertas. Menurut psikologi, anak adalah periode pekembangan yang merentang dari masa bayi hingga usia lima atau enam tahun, periode ini biasanya disebut dengan periode prasekolah, kemudian berkembang setara dengan tahun tahun sekolah dasar. Istilah anak juga sering merujuk pada perkembangan mental seseorang, walaupun usianya secara biologis dan kronologis seseorang sudah termasuk dewasa namun apabila perkembangan mentalnya ataukah urutan umurnya maka seseorang dapat saja diasosiasikan dengan istilah "anak".

Keluarga memiliki peranan penting dalam masa pertumbuhan dan perkembangan anak, terutama pada era saat ini dimana teknologi sudah berkembang dan banyak kejahatan yang terjadi di sekitar kita. Tidak hanya orang dewasa yang memiliki hak, seorang anak juga memiliki hak - hak yang harus dihormati dan dipenuhi oleh orangtua. Seorang anak yang hak - haknya terpenuhi akan tumbuh menjadi anak yang sehat, bahagia, dan berpeluang lebih sukses. Bila hak yang dimiliki anak tidak terpenuhi, maka salah satu akibatnya seorang anak bisa terjerumus kedalam kenakalan remaja.

Kenakalan remaja adalah wujud dari konflik yang tidak terselesaikan dengan baik pada masa kanak - kanak maupun pada saat remaja. Kenakalan remaja adalah 
pelampiasan masalah yang dihadapi oleh kalangan remaja yang tindakannya menyimpang. Menurut ahli sosiologi Kartono, Kenakalan Remaja merupakan gejala patologis sosial pada remaja yang disebabkan oleh satu bentuk pengabaian sosial. Akibatnya, mereka mengembangkan bentuk perilaku yang menyimpang. Sedangkan menurut Santrock "Kenakalan remaja merupakan kumpulan dari berbagai perilaku remaja yang tidak dapat diterima secara sosial hingga terjadi tindakan kriminal."

Kenakalan remaja memiliki dua faktor, yaitu faktor internal dan faktor eksternal dimana faktor internal seperti krisis identitas dan kontrol diri yang lemah sedangkan faktor eksternal meliputi kurangnya pengawasan terhadap anak, kurangnya disiplin yang diterapkan orangtua, rendahnya kualitas hubungan orangtua-anak, dan kekerasan dalam lingkungan keluarga. Penyebab kenakalan remaja tersebut bisa saja terjadi bila kedua orangtua tidak memenuhi hak - hak anak yang dapat mengganggu mental seorang anak hingga ia melakukan sesuatu tanpa pikir panjang dan dapat berakibat fatal.

Pada tahun 2013 angka kenakalan remaja di Indonesia mencapai 6325 kasus 147 kasus tawuran antar pelajar, sedangkan pada tahun 2014 jumlahnya mencapai 7007 kasus 255 kasus tawuran antar pelajar dan pada tahun 2015 mencapai 7762 kasus. Angka kasus kenakalan anak-anak dan remaja mendominasi kasus yang ditangani Bidang Pemberdayaan Perempuan dan Perlindungan Anak Dinas Sosial, Pemberdayaan Masyarakat dan Desa Kabupaten Belitung Timur. Hingga Mei 2020 ini, dari total 8 kasus yang ditangani, 5 diantaranya merupakan kenakalan remaja.

\section{Kasus / Masalah}

1) Kenapa lingkungan keluarga menjadi hal yang paling penting dalam perkembangan karakter anak?

2) Apa akibat / dampak bila hak - hak anak tidak terpenuhi?

3) Apa kewajiban orangtua terhadap anak?

\section{Tinjauan Pustaka}

Menurut Gunarsa (2009:5) "lingkungan keluarga merupakan lingkungan pertama yang mula-mula memberikan pengaruh yang mendalam bagi anak". Pendapat lainnya tentang lingkungan keluarga menurut Hasbullah (2008:3) yaitu "lingkungan keluarga merupakan lingkungan pendidikan pertama dan utama bagi anak, karena dalam keluarga inilah anak pertama - tama mendapat didikan dan bimbingan. Dan dikatakan sebagai lingkungan yang utama karena sebagian besar dari kehidupan anak adalah didalam keluarga". 
Pengertian perlindungan anak menurut UU Nomor 35 tahun 2014 tentang perubahan atas UU Nomor 23 tahun 2002 tentang perlindungan anak adalah segala kegiatan untuk menjamin dan melindungi anak dan hak - haknya agar dapat hidup, tumbuh, berkembang, dan berpartisipasi secara optimal sesuai dengan harkat dan martabat kemanusiaan, serta mendapat perlindungan dari kekerasan diskriminasi.

Menurut pakar tumbuh kembang, ada 3 kebutuhan dasar yang harus dipenuhi agar anak bisa tumbuh optimal pada masa perkembangannya, yaitu :

1) Kebutuhan dasar kesehatan dan gizi yang baik, antara lain dengan pemberian nutrisi seimbang.

2) Kebutuhan dasar kasih sayang. Sejak dalam kandungan hingga usia 2-3 tahun, kasih sayang orangtua akan sangat mempengaruhi pembentukan karakter dan kepribadian anak serta rasa aman dan nyaman.

3) Kebutuhan dasar stimulasi. Kreativitas dan kecerdasan yang bagus hanya bisa diperoleh anak-anak dengan adanya stimulasi dari orang-orang di lingkungan sekitar, sehingga orangtua berkewajiban membangun lingkungan yang kondusif bagi tumbuh kembang anak.

Kenakalan remaja menurut Kartini Kartono (2010) ialah perilaku jahat atau kenakalan anak - anak muda yang merupakan gejala sakit (Patologis) secara sosial pada anak remaja yang disebabkan oleh satu bentuk pengabaian sosial, sehingga mereka itu mengembangkan bentuk tingkah laku yang menyimpang.

\section{Pembahasan}

Lingkungan keluarga menjadi hal yang paling penting dalam perkembangan seorang anak karena keluarga merupakan wahana / media utama dan pertama dalam pendidikan dan penyemaian nilai-nilai luhur bangsa kepada anak-anak. Keluarga mempunyai delapan fungsi, yaitu fungsi agama, kasih sayang, reproduksi, perlindungan, sosialisasi dan pendidikan, ekonomi, sosial budaya, dan pelestarian lingkungan. Sejak seorang anak dilahirkan, ia akan mempelajari hal - hal mendasar dari lingkungan keluarga, terutama dari orangtua yang memberikan contoh perilaku, tutur kata, serta mengajarkan norma - norma dalam hidup yang baik agar diteladani seorang anak.

Terdapat beberapa dampak yang dapat ditimbulkan dari tidak terpenuhinya hak seorang anak, kenakalan remaja merupakan salah satunya. Seorang anak anak yang terjerumus ke dalam kenakalan remaja pasti ada penyebabnya baik dari faktor lingkungan sekolah, lingkungan keluarga, maupun lingkungan masyarakat. Peran orangtua sangat dibutuhkan untuk mendampingi dan menuntun seorang anak agar dapat tumbuh dan berkembang di jalan yang benar. 
Kewajiban orangtua terhadap anak merupakan upaya yang harus dilakukan orangtua dalam memenuhi kebutuhan seorang anak. Kewajiban orangtua terhadap anak tertuang dalam UU Nomor 35 Tahun 2014 tentang perubahan atas UU Nomor 23 Tahun 2002 tentang perlingungan anak pasal 26 mengatakan bahwa kewajiban orangtua terhadap anak mecakup beberapa hal yaitu :

a. Mengasuh, memelihara, melindungi, dan mendidik anak

b. Menumbuh kembangkan anak sesuai dengan kemampuan, minat, dan bakatnya

c. Mencegah anak menikah pada usia dini

d. Memberikan pendidikan karakter dan penanaman nilai budi pekerti anak

Peran orangtua sangat penting bagi pekembangan anak, karena seorang anak pertama kali mendapat pelajaran dari lingkungan keluarga terutama orangtua. Maka orangtua haruslah memberikan pengajaran dan dapat berpengaruh positif serta menjadi sosok yang dapat diteladani seorang anak karena nantinya akan menjadi bekal seorang anak dalam menjalani kehidupan. Orangtua harus memenuhi hak - hak yang dimiliki seorang anak dengan menjalankan kewajibannya sebagai orangtua agar anak dapat tumbuh dan berkembang dengan bahagia. Orangtua dapat dan sangat dianjurkan mengikuti program parenting untuk mempersiapkan diri ketika memiliki anak.

\section{Kesimpulan}

1) Lingkungan keluarga yang baik merupakan hal yang paling penting dan utama dalam masa perkembangan seorang anak, karena di lingkungan keluargalah anak akan mendapatkan pendidikan pertama kali terutama peran dari orangtua. Dukungan dari anggota keluarga lainnya juga berpengaruh dalam pembentukan karakter diri seorang anak dengan menanamkan kebiasaan tentang hal mana yang baik sehingga anak-anak menjadi paham mana yang benar dan salah. Serta menanamkan sikap budi pekerti dengan landasan budi luhur harus di lakukan dengan memberi banyak contoh - contoh yang nyata.

2) Kenakalan remaja merupakan salah satu kasus yang sering dijumpai dalam masyarakat dengan berbagai latar belakang, salah satunya disebabkan oleh lingkungan keluarga yang tidak harmonis atau broken home. Kurangnya perhatian serta kasih sayang dari orangtua dan keluarga menjadi hal yang umum dijumpai saat ini. Seorang anak dapat berbuat nekat atau melakukan suatu tindakan menyimpang yang dilakukan tanpa berpikir panjang dan tidak memikirkan dampak yang akan ditimbulkan dari perbuatannya.

3) Setiap anak yang baru saja dilahirkan memiliki hak anak yang sama dan harus dipenuhi oleh keluarga, terutama orangtua karena semuanya berawal dari keluarga. Dalam pemenuhan hak seorang anak, orangtua dapat melakukan kewajibannya 
yang tertuang dalam UU Nomor 35 Tahun 2014 tentang perubahan atas UU Nomor 23 Tahun 2002 tentang Perlindungan Anak. Setiap anak juga berhak mendapatkan standar kesehatan dan perawatan medis yang terbaik, air bersih, makanan bergizi, dan lingkungan tinggal yang bersih dan aman.

\section{Daftar Pustaka}

\section{Sumber Artikel dan Jurnal :}

Karimah, D., Nurwati, N., \& Basar, G. G. K. (2015). Pengaruh Pemenuhan Kesehatan Anak Terhadap Perkembangan Anak. Prosiding Penelitian dan Pengabdian kepada Masyarakat, 2(1).

Ummah, S. A., \& Fitri, N. A. N. (2020). Pengaruh Lingkungan Keluarga terhadap Perkembangan Sosial Emosional Anak Usia Dini. SELING: Jurnal Program Studi PGRA, 6(1), 84-88.

Bayna, I. M. (2017). PERAN ORANGTUA DALAM OPTIMALISASI TUMBUH KEMBANG ANAK UNTUK MEMBANGUN KARAKTER ANAK USIA DINI. Jurnal Kewarganegaraan, 1(2), 41-43.

https://kompaspedia.kompas.id/baca/paparan-topik/hak-perlindungan-dan-persoalananak-di-indonesia

\section{Sumber Lainnya :}

UU Nomor 35 Tahun 2014 tentang perubahan atas UU Nomor 23 Tahun 2002 tentang perlindungan anak 